\title{
Your Local Cloud-Enabled Library
}

George K. Thiruvathukal

Loyola University Chicago, gkt@cs.luc.edu

Follow this and additional works at: https://ecommons.luc.edu/cs_facpubs

Part of the Computer Sciences Commons

\section{Recommended Citation}

George K. Thiruvathukal, "Your Local Cloud-Enabled Library," Computing in Science and Engineering, vol. 12, no. 4, pp. 5-6, July/Aug. 2010, doi:10.1109/MCSE.2010.94

This Article is brought to you for free and open access by the Faculty Publications and Other Works by Department at Loyola eCommons. It has been accepted for inclusion in Computer Science: Faculty Publications and Other Works by an authorized administrator of Loyola eCommons. For more information, please contact ecommons@luc.edu.

\section{(c) (1) $\$ \odot$}

This work is licensed under a Creative Commons Attribution-Noncommercial-No Derivative Works 3.0 License. Copyright @ 2010 George K. Thiruvathukal 


\title{
F R O M \\ THE E DITORS
}

\section{Your Local Cloud-Enabled Library}

\author{
By George K. Thiruvathukal, Associate Editor in Chief
}

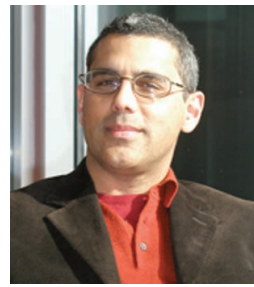

HEN I FIRST JOINED COMPUTING IN SCIENCE AND ENGINEERING AS A

COEDITOR FOR THE SCIENTIFIC PROGRAMMING DEPARTMENT, MY

PARTNER IN CRIME, PAUL DUBOIS, PENNED A SIDEBAR THAT INCLUDED A DIS-

\section{CUSSION ABOUT LIBRARIES. ${ }^{1}$ FOR EFFECT, HE WENT SO FAR AS TO SPELL IT}

out with hyphens between each letter (L-I-B-R-A-R-Y), almost as if he were introducing a word that had become foreign to the many who increasingly thought that if something wasn't on the Web, it couldn't possibly exist.

During a recent visit with my family to the Chicago Public Library, I had a great epiphany: Libraries do matter and are crucial to preserving and promoting knowledge and culture. I'm sure this epiphany is experienced by many people everyday — especially those who love reading/ writing as we do-but this idea is endangered nevertheless by those who think the world could do without libraries, simply because so many things are moving online and are available electronically.

It's true that technological advances threaten the library concept as we know it. Still, the library has an extremely important role to play in the future of education and communities around the world, and-however crazy it might sound to some-I believe that role will survive almost intact. For that to occur, we must take every step to protect these resources and ensure that libraries remain a cultural value, even as the winds of technology buffet them with fierce side and head winds.

Back to my visit, though. I was delighted to see that my branch seemed to get it in a technological sense. On a piece of paper tacked to one of the beams in the middle of the library were words to this effect:

If you need to create or save a document to a bard drive, consider using Google Documents or Zoho Office.

\section{If you need to create a resume, consider using WebResume.com}

Being ever the technology geek, and lacking a pen, I would add: To check your voice mail transcriptions, consider using voice. google.com. I'm sure you can think of many other relevant examples.
As these notices show, libraries are an important onramp for technology. Sure, they're known for making books accessible and have been pioneers in database access, but my branch seemed to understand that it has a vital cultural role to play, especially when it comes to technology access. Most people in American society presume such access is ubiquitous, even though a substantial percentage of the world population lacks access.

I find the notion that anyone in the public-especially the "tired and poor" that Lady Liberty embraces-can access technology, even if they can't afford a computer, a broadband connection, or even a home with electricity to power such gizmos, to be a powerful, liberating, and transformative concept. While there's still much more needed to truly empower people (such as access to food, shelter, and education/training), this is a promising step that I hope will be replicated on a grand scale throughout the world. In my travels, I've found that libraries and Internet cafes (a low cost, but not free option) are an on-ramp for many who either choose not to have or can't otherwise obtain Internet access of their own. With time and wireless technology, the Internet will reach most of the world, but there will almost inevitably be people who never get it for one reason or another and will need the library. Knowledge is for everyone!

Back to the library's central mission: to promote and preserve knowledge and culture. My university established an "information commons" a few years ago for the entire student/faculty population. This space, which is directly connected to the traditional campus "library," offers an onramp for access to collaborative spaces and digital resources, yet is connected to the old campus library that remains in use.

The commons idea recognizes that access to information and the ability to collaborate are central to our 
intellectual and cultural future and are becoming a much more social endeavor. We were by no means the first to set up this kind of space, which exists at many other institutions in one form or another. With a growing amount of knowledge on the Internet, including digital books and open courseware (as notable examples), libraries will need to become more like these information commons and expand their services to allow such resources to be accessed, much like a computer is accessed for the basic abovementioned services.

o, you might ask, what does this have to do with CiSE? Taken at face value, absolutely nothing. But there is clearly something at work here. We're in the knowledge business. Much like the services from Google and WebResume, we'll increasingly provide knowledge in the form of cloud-enabled applications. These applications must be designed with an eye to the world that might well want to access them.

In the coming years, we (like many other publications) will need to augment what appears on the "printed" page with rich content, lest we become obsolete. So, to the readers who also write for us, please be thinking about how your articles can link to resources that can be studiedinteractively-in a library. You never know: the next computational "thinker" might be reading (or watching) it ... somewhere on planet Earth.

\section{Reference}

1. P.F. Dubois, "Scholarzheimers," Cafe Dubois, Computing in Science \& Eng., vol. 6, no. 2, 2004, pp. 86-92.

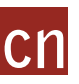
Selected articles and columns from IEEE Computer Society publications are also available for free at http://ComputingNow. computer.org.

\begin{tabular}{|c|c|c|}
\hline & 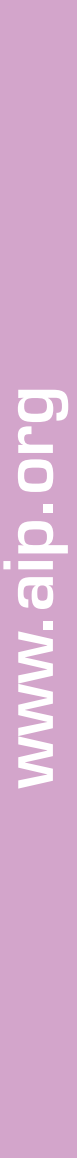 & 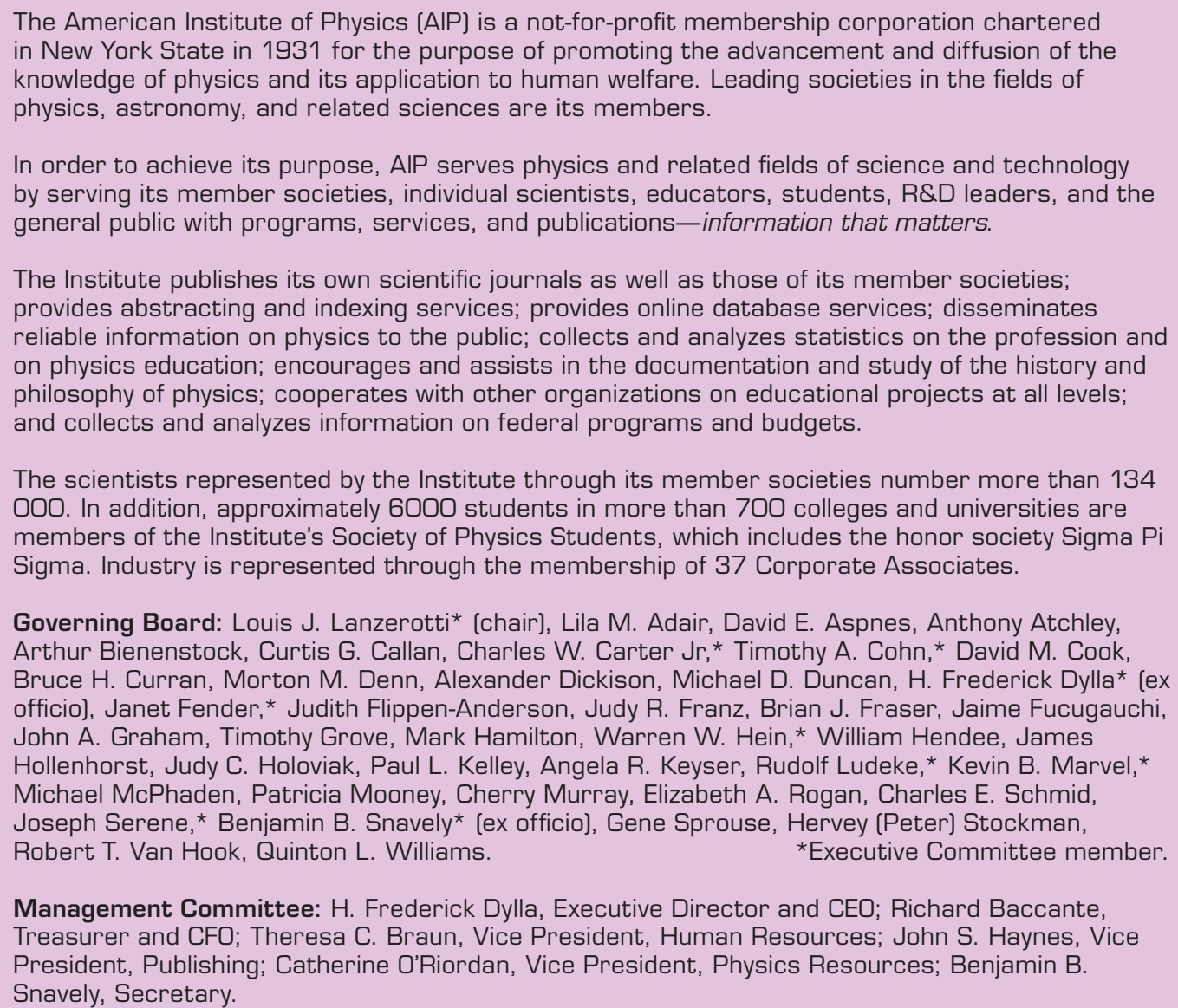 \\
\hline
\end{tabular}

